University for Business and Technology in Kosovo

UBT Knowledge Center

UBT International Conference

2015 UBT International Conference

Nov 7th, 9:00 AM - 5:00 PM

\title{
Money Laundering Effects
}

\author{
Mario Gjoni \\ University of Tirana, mariogjoni@gmail.com
}

Albana (Karameta) Gjoni

Agricultural University of Tirana, gjoni.albana@gmail.com

Holta (Bako) Kora

European University of Tirana, holtabako@yahoo.com

Follow this and additional works at: https://knowledgecenter.ubt-uni.net/conference

Part of the Business Commons

Recommended Citation

Gjoni, Mario; Gjoni, Albana (Karameta); and Kora, Holta (Bako), "Money Laundering Effects" (2015). UBT International Conference. 16.

https://knowledgecenter.ubt-uni.net/conference/2015/all-events/16

This Event is brought to you for free and open access by the Publication and Journals at UBT Knowledge Center. It has been accepted for inclusion in UBT International Conference by an authorized administrator of UBT Knowledge Center. For more information, please contact knowledge.center@ubt-uni.net. 


\title{
Money Laundering Effects
}

\author{
Mario Gjoni ${ }^{1}$, Albana Gjoni (Karameta) ${ }^{2}$, Holta Kora (Bako) $)^{3}$ \\ ${ }^{1}$ University of Tirana, Faculty of Economy, Marketing Department \\ ${ }^{2}$ Agricultural University of Tirana, Faculty of Economy and Agribusiness, Finance and \\ Accounting Department \\ ${ }^{3}$ European University of Tirana, Faculty of Economy, Finance and Accounting \\ Department \\ mariogjoni@gmail.com¹, gjoni.albana@gmail.com² \\ holtabako@yahoo.com ${ }^{3}$
}

\begin{abstract}
The globalization of economic activities and financial markets has had a very positive impact on the world economy. But this effect has also its costs. It can facilitate the ways by which money can be laundered internationally which is one of the biggest costs that this phenomenon creates. Among many analysts there is a discussion about the relationship that exists between globalization and money laundering, as well as economic implications of large-scale money laundering. Money laundering threatens the economic and financial systems in many countries, and has important effects on income distribution and macroeconomic variables. The negative effects of money laundering on economic development are difficult to measure, but it is obvious that such activity seriously damages the financial sector economy by diverting resources, encourages crime and corruption and distorts the trade indicators in the international sector. The main focus of this paper is the effect and impact that money laundering has in the agencies and institutional structures as well as the global financial consequences that brings this criminal activity.
\end{abstract}

Keywords: Money laundering, Albania, Balkans, Fighting Crime

\section{Money Laundering and Macroeconomic Effects}

\section{What is Money Laundering?}

Money laundering is the process of disguising illegal sources of money in order to appear legitimate. Money laundering methods are different and sophisticated. Money laundering has had its beginnings in the early 1930s, in the US, in this period, after the prohibition of the production of alcoholic beverages by private and monopolization of this activity, pirate manufacturers continuing this activity began to ensure fat profits. These profits that were obtained illegally, pirate manufacturers tried to 'launder' them in legal activities. Therefore from making the illegal money legal it comes the name of money laundering. While in the past 15 years they are taken very important steps, not only toward the consolidation of the legislation but also for ratification, signature, and implementation of international conventions. Money laundering is a term commonly used to describe the ways in which criminal elements address the benefits illegally, known as dirty or illegal money, and derived from illegal activities such as: income from drugs, prostitution, fraud, etc. The laundering of these money is often done through transfers or financial actions in order to disguise the source of these funds to make them look like they are of a legal nature. The name came from the beginning of the twentieth century when criminals used the laundry businesses to justify large amounts of income in the eyes of control when actually they were completely made on illegal activities.

Governments in each country proclaim every year a quota assessment for the amount of money laundered within their national economy. In 1996 the International Monetary Fund estimated that 2\% - 5\% of the global economy worldwide is involved in money laundering. However, the Financial Action Task Force (FATF), an intergovernmental body set up to combat money laundering, admits that it is absolutely impossible to issue a credible estimate of the amount of money laundered and 
therefore the FATF does not publish any figures in this regard. Although money laundering does not require the use of formal financial institutions, the results consistently show that banks, capital markets and institutions, non-banking financial companies such as insurance, foreign exchange offices, and notaries are a tool to favor clearing illegal funds domestically and internationally.

\section{Cycle of Money Laundering}

International practice Money laundering is a process that is articulated in three stages, which make the merger of funds obtained illegally, with legal funds that enter the legal economic cycle.

1. Setting is the entry in which "the cleaner" puts his illegal money in the legal financial system, using all financial instruments available, from the most sophisticated methods, to the simplest method, as can be sharing large amounts in smaller parts and depositing them in a bank, with different names, later, these funds will be reunited and deposited into bank accounts of other localities. This is the point at which benefits are most visible and the crime can be better detected. At this stage the illegal money is often in the form of cash. Usually tempted to engage in this game are deposit institutions, such as: banks or money transfer businesses, this phase is called the "Pre-wash".

2. Hiding the origin of capital or coverage. This stage will involve the transfer of funds previously entered into the legal financial system, converted, or simply transferred from one bank to another. So the dirty money is being spent on a range of transactions, in order to conceal the true origin. These transactions may include investments in various entities, such as companies and trust funds, various financial assets such as stocks or insurance policy institutions etc. This phase is also called masking. 3. Resolution of capital Admission called also "integration" involves the illegal funds that are at this stage almost legal, that enter the economic cycle to be investing or converted into goods or real estate value. Criminals are free to enjoy their benefits without being too afraid that can be identified as criminals. This phase is also called washing or laundering. Money laundering is a phenomenon that comprises in itself two different crimes. The main crime is the way of income to be cleaned and then the transfer of these funds illegally in legal activities. Money laundering is an ever going problem in most countries of the world. Generally, money laundering subjects find space of action in those areas where there are no strict rules and programs to combat money laundering or where they are too lenient. Areas with an unstable financial system seem exactly the victim countries.

It is noticed that in the first phase the money moves near or around the source in the place where the primary activity is held. While the preferred stage of money alienation is to make transfers abroad, perhaps in places with large local markets, or an international banking center. However at this stage funds can be distributed in different bank accounts in different areas, where this movement can be made without leaving clues that could create doubts about the origin or final destination of these funds.

4. Finally, the stage of integration, launderers choose to invest their funds in areas that offer the greatest opportunity and profit. The forms and methods of money laundering are also 2 known forms of organized crime:

- Horizontal Crime (Mafia)

- Crime with vertical extension (Cartels)

A characteristic of horizontal control is the control of the territory of a given area and the exercise of many types of criminal activities.

Vertical control mainly deals with one type of criminal activity. For example, cocaine is controlled by the leaf to the sale of its output. So the "boss" of cocaine controls all activity in the vertical position, from plant cultivation, processing, transport and sale. The common purpose of all criminal narcotics activity is the realization of profits. But the cycle of this criminal activity is not yet closed. These sums of money must laundered in the interests of traffickers. It is a quite large amount of financial investment that in any state would be immediately noticeable. These money brings along many inequalities such as: creates an unfair competition, forcing to bankruptcy many normal activities of manufacturing and commercial, so there are many harmful economic and social consequences. Many states provide strict legal controls on the sources of income of their citizens. This obliges the authors of criminal activity to put into circulation the money through other secret ways uncontrolled by the state. But this activity is a risk with double social consequences:

- In the first place it seriously damages the economy of the country where the business is conducted.

- Secondly it promotes criminal activity 
This creates trust and confidence among the criminals and helps them increase their financial income. For these reasons, every country signed and approved numerous laws against this process. Albanian Criminal Code also provides this activity as an offense.

Article 287 and Article 287 / a predict:

"Diversification, transfer, harboring, the disguise of the nature, of the source and the belonging of a property is a criminal activity punishable by $3-10$ years."

"When this offense is committed in collaboration or more than once, shall be punished by imprisonment from 7 to 15 years, and if this has brought serious consequences, with imprisonment of not less than 15 years" (Article 287 / a).

\section{Methods of Money Laundering}

There are many known methods that are used in money laundering, some of them or the channels that are used to do this are mentioned below:

- Transactions in the financial sector.

- Opening multiple bank accounts in the name of family members.

-Purchase or entering into cooperation with commercial companies, construction or transport firms.

- Opening of companies abroad.

- Purchase of real estate.

- Purchase of luxury goods, etc...

\section{Macroeconomic Analysis}

The effects that money laundering brings into an economy are numerous and most of the time hazardous to the economy of the state. This process directly affects the financial economy and the financial sector in addition impacts on many other sectors. The major effects of money laundering are:

\section{Deformation in Consumption}

Shortly after the money is transferred from the owner to the beneficiary, the latter would use them in the best way possible. But this money laundering in its activity, involving the purchase of assets such as real estate, jewelry, works of art and many other products luxury, allows cleaners to hide and clean the first track without waking doubts. This directly affects the consumer deformation.

\section{Artificial Price Growth}

Money launderers are encouraged to invest their income illegally in order to become legitimate. As a result, they are willing to pay for their purchases more than their real value, this leads to a price disequilibrium by an artificial increase in the prices. Money launderers engage in large purchases, due to higher availability of funds, surpassing potentially honest buyers. To hide their illicit funds, money launderers are able to pay much more than the true value of the property, causing an artificial movement of purchases, making them unaffordable by honest buyers.

\section{Affects Growth rates}

Money laundering has a significant negative impact on the pace of economic growth of a country. Funds are redirected from healthy and successful activities in slower and more dangerous activities, from international healthy and productive investments into criminal sterile investments. When a company or industry is not attractive by money launderers, they tend simply to abandon it causing the potential collapse of these sectors and cause serious damage to the economy. Money laundering has a damaging effect on financial institutions, which are crucial to economic growth. But, money laundering could also have positive effects on economic growth of a country, this happens when a country is a transfer place of criminal money, like the fiscal paradises or other similar countries. If money is transferred from a criminal activity in another country to be laundered then the criminal past of this money has not negative effects in the host country.

\section{Illegal Businesses Infect Legitimate Ones}

Illegal transactions can infect legitimate ones. According to researchers, many legal transactions have become less attractive for foreign investors because of the suspicion that the other society deals with money laundering. This is because involving into the illegal activities of a society makes other agents in the economy mistrust and alienate their investments. 


\section{Corruption and Bribery}

Laundering money promotes corruption and bribery not only in financial institutions but also in other economic sectors. First, it affects the financial institutions in which illegal income is being processed. But, money laundering is carried out not only in financial institutions, it includes a lawyer and a notary public, who collaborate, making these professions vulnerable to corruption. Thus, institutions may be attracted by criminals in an active collaboration becoming part of the criminal network. This effect expands up to professionals like lawyers, bankers, accountants, by reaching to the political officials responsible for financial market regulation. Thus the effect of corruption is not limited only to the financial sector. Once money launderers are infiltrated a given economy, they will invest further giving bribes to public officials in order to gain control of the biggest sectors in the economy.

\section{Increases Crime}

Money laundering can be considered as a multiplier of criminal activities, giving criminals economic power. As such, it makes crime able to perform by allowing criminals to use their illicit proceeds. Laundering money facilitates crime because criminal organizations look legitimate, giving opportunity to answer those sponsored, diversify and expand themselves. In countries with weak economies and weak law legislation against crime, there exists a negative relationship between economic crime and money laundering, as happens that these negative effects outside followed in neighboring countries which are more economically developed. This result derived from a costbenefit analysis. Policy makers will choose to follow the rules of anti-money laundering only if national anticipated benefits are higher than expected costs of international engagement.

\section{Destabilizes Political Institutions}

If a money launderer manages to retain a significant part of the economy, then he can try to increase political control, and to extend his goals. These goals are achieved through corruption, bribery or messing with elections and votes, which will affect the essence of the democratic process of the country. As noted above these processes can significantly damage the political and economic process of the country.

\section{Money Laundering in Eastern European Countries}

\section{CARPO Project}

CARPO project is a joint technical project of the Southeast European countries such as: Albania, Kosovo, Macedonia, Bosnia and Herzegovina, Croatia and Montenegro. All these countries are conscious of the fact that prevention and prohibition of organized crime and economic crime depends greatly on a deep knowledge of these phenomena. International full implementation of the policy of national crime and harboring a good cooperation and functional implementation are a must in order to have good results. Economic crime which seriously affects all project areas in the region continues to develop. Amendment of legislation should increase revenues and decrease tax evasion, however, in the region there are still many opportunities to illegal trades, money multiplication and falsified documents. Meanwhile, the negative influence that these serious crimes have on the economy, societies and democratic development of these countries.

In 2012, Albania, Croatia, Montenegro and Serbia have investigated separately around 3500 issue and more than 4,000 perpetrators and the number of crime groups range from 400 to 500, what means that in all the countries of the zone Eastern Europe active number of crimes is much higher and increased by $50 \%$ compared with the previous year. Investigators of the Council of Europe have chosen to highlight that there are close grounds connection between organized crime and economic crime, in particular corruption and money laundering.

Safety, integrity, the stability of financial institutions and confidence to the financial system as a whole may be jeopardized by the efforts of criminals and their associates to alienating the origin of their income, or to channel legal money for terrorist purposes. Income received illegally can be re invested in criminal businesses or illegal businesses.

Bosnia and Herzegovina $(\mathrm{BiH})$ in 2012 reported 16 cases $(+100 \%$ more than in 2011). The value of the money laundered is approximately 26.5 million euros, of which 1 million euros are thought to have come from tax evasion. In 2012 were registered 2 cases of money laundering and in 2013 the Federation of $\mathrm{BiH}$ police reports statistics only 1 case of laundering money. 
Croatia reported an average of 1.5 million proceeds of crime, while the figure rose in 2012, reaching 54 million euros generally shared by drug trafficking and other economic crimes. Croatian coast is thought to be most profitable and attracts many domestic investors such as Russian investors. In the period 2006-2010, the Croatian police investigated 42 criminal acts of money laundering. In 20102012 it is reported minor cases of money laundering nearly 27 cases. Whereas in 2013 the Croatian police has analyzed 282 cases, of which 81 sent it to the competent authorities.

Kosovo, for the first time the Financial Intelligence Unit has reported around 65 suspicious financial transactions in 2012.

In Montenegro, the most vulnerable sector to money laundering seems to be the coast, which is attractive for legitimate business also. While coastal area bordering Albania and roundings of city of Ulcinj seem more attractive to illegal capital. In 2010 Montenegro has reported only two charges and blocked a total of 10.9 million dollars. While, in 2011 reported 10 cases of money laundering achieving the figure of 23.4 million dollars.

In Serbia, large quantities of products appear to come from tax evasion and customs, but also from drug trafficking, human trafficking, and violent crime. Laundered activities through privatization process and through the purchase of real estate and assets. Only in 2011 there were confiscated around 650,000 euros and 2 million dollars.

By studying these data can see in the graphic amount of laundered money confiscated in 2012 in the following countries:

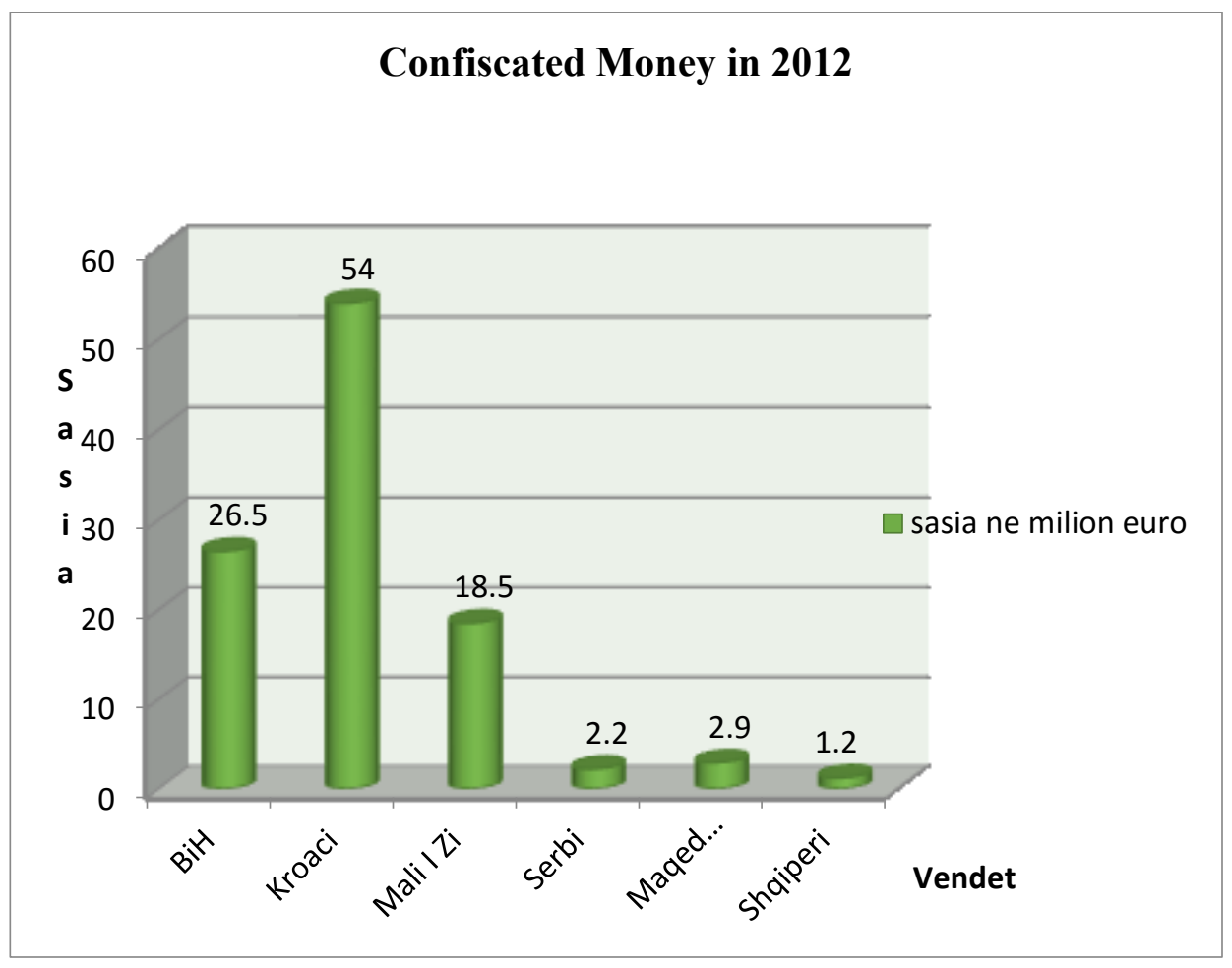




\section{The Budget of the Financial Intelligence Unit (FIU)}

Financial Intelligence Unit, had the budget and separate account since 1 August 2005, by attaining have a potential increased independence and the budget. During 2005, the budget available to FIU started with the value 10,520 thousand, while the forecast catch value 13,800 thousands leke and over the years has changed its value with an upward trend, confirming the priority that the government has paid consistently Unit Financial intelligence in general and prevention of money laundering and financing of terrorism.

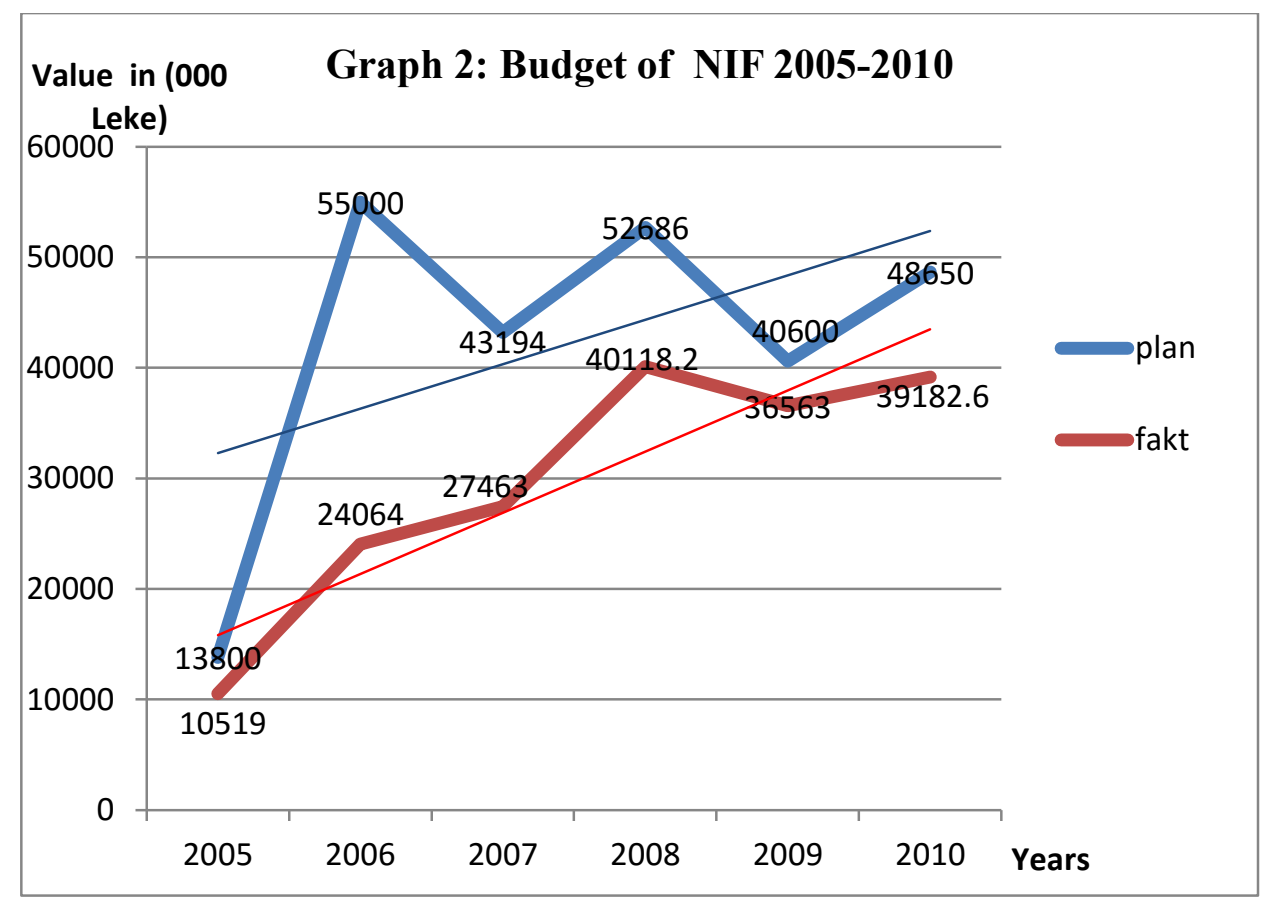

The graph shows concisely budgetary resources available to the Financial Intelligence Unit and their use from 2005 to 2010 . As it is clear from the data available under the NIF funds have always been higher than what is used in fact. Despite reductions in 2007 and 2009, which once again confirm the priority that government has given to NIF in the fight against money laundering and financing of terrorism. In comparison with 2005, in 2006 the budget increased for the NIF according to the plans that have been realized. In 2007 the budget is exploited up to the extent of $63.6 \%$ and in year 2008 $76.1 \%$ of the budget was used and in 2009 used $90 \%$ of the budget. In $2010,80.5 \%$ of the budget used. These are good numbers that the money or the budget that the government allocates are used properly in the fight against corruption and organized crime. 


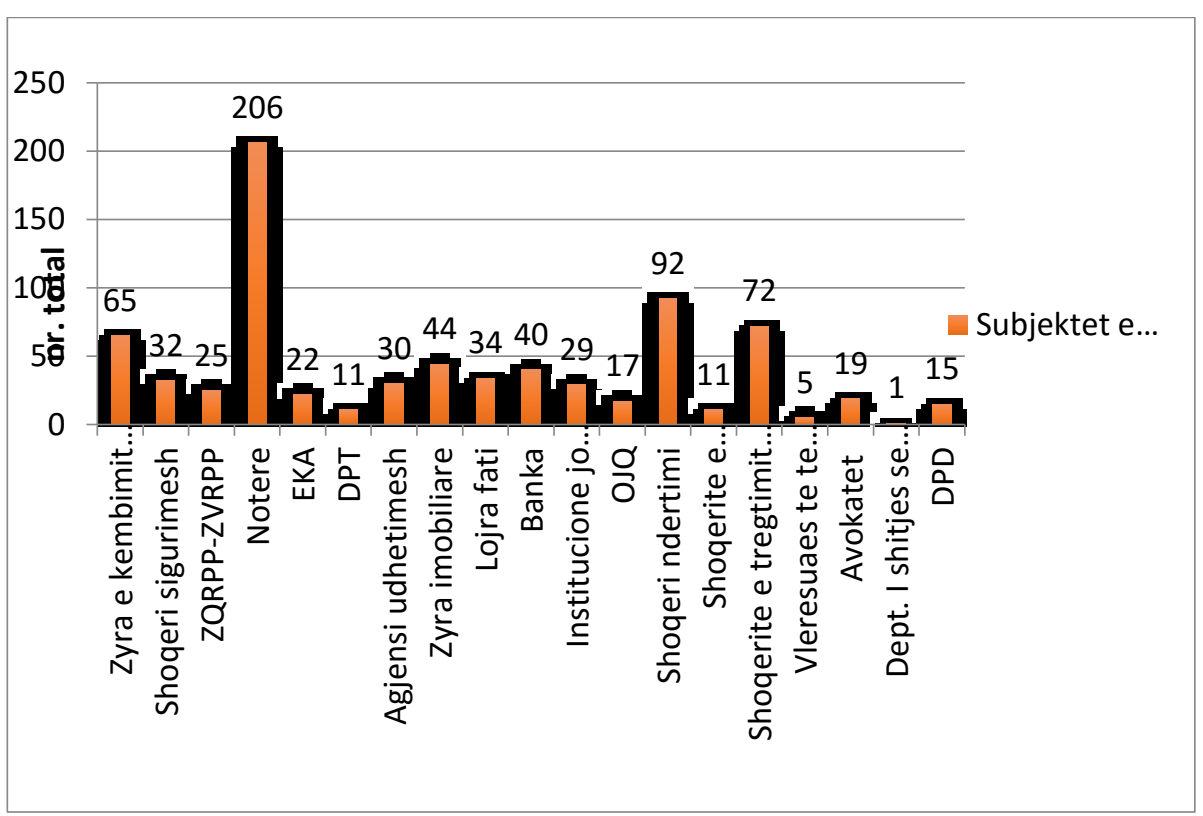

\section{Conclusion}

In Albanian economy the issue of money laundering as a phenomenon of global proportions continues to be part of the Albanian reality in recent years. It hinders the integration of Albania into the EU due to the necessity of implementation of the requirements of international institutions in this regard. In matters of declaration of assets or revenues there is a law but much more should be done. Banks have responded as a moral and social responsibility to combat money laundering, because of the strong links between money laundering and serious crime, because by strengthening control it can be reduced the extent of money laundering, and increases the possibility that criminals are caught and punished. While at international level money laundering, financial crime and the financing of terrorism has distorted the myth of capital neutrality. The ability of money to flow freely within and between countries, markets, has brought huge benefits, allowing companies to engage in the form of flexible funding. These positive effects have encouraged states to compete for very large capital which move from one market to another in search of investment opportunities. It has also brought new risks. Criminals, corrupt officials, entrepreneurs, officers of the companies and the terrorists are all able to abuse with the financial system and engage afterward in money laundering. This presents new risks to the integrity and reputation of the financial system. It also has maximum potential to undermine social capital and bring economic consequences this way.

In these last 20 years of law improvement by FIU's authorities and other institutions are making great steps in identifying new ways of laundering money. However, the emphasis continues to be placed in small operations of money laundering, which tend to highlight crime (drug distribution, fraud, etc.). There is not sufficient knowledge of how much money is laundered and continues to do so every day. New measures require further investigation to find large amounts of money which are being laundered into the system.

Another point particularly vulnerable to money laundering are unregulated transactions through banks which face the first of the many risks for their finances, also are the first institution where the investigation begins. Study of money laundering activities and the risks they carry need to be done on real properties, in order to have accurate results and not distortion of the market figures. 


\section{References}

1. Guide to "Anti-Money Loundering and Gabating the Financing of Terrorism", P 1-9.

2. Walker, J. (1999). 'How Big is Global Money Laundering?'.Journal of Money

i. Laundering Control, Vol. 3, No. 1

3. Quirk, P.J. (1996).'Macroeconomic Implications of Money Laundering'.

4. Tanzi, V. (1997). 'Macroeconomic Implications of Money Laundering'.p 91-104

5. Calvin Lee Pacleb, "Internacional Money Loundering, A Compresive Revieë and General Theory of Corruption”, B.S, A Thesies in Economics.

6. World Bank Institute "Anti-Maney Loundering Literature Search Economics".

7. May 2010, "Money Lounderin and Financial Crimes", Country Database.

8. Jan-Dec 2004, European Central Bank, "Monthly Bulletins".

9. FATF (1997-2003), "Financial Action Task Force", Annual Reports

10. World Trade Organization (2005). 'Statistics Database'.Geneva: ËTO

11. www.fint.gov.al

12. http://search.state.gov

13. [HTML] - 2008-02-29 - Volume II: Money Laundering and Financial Crimes 2008 International Narcotics Control Strategy Reportwww.state.gov/p/inl/rls/nrcrpt/2008/vol2/

14. [HTML] - 2011-03-03 - Major Money Laundering Countries 2011 International Narcotics Control Strategy Report INCSR - Major Money Laundering Countries www.state.gov/p/inl/rls/nrcrpt/2011/vol2/156373.htm

15. http://www.state.gov/documents/organization

16. www.bankofalbania.org

17. Texas Teach University http://etd.lib.ttu.edu

18. www.minfin.gov.al

19. www.justic.gov.al

20. www.coe.int/moneyval

21. www.reuters.com

22. http://www.bankofalbania.org Rregullore Nr.44 "Për parandalimin e pastrimit të parave dhe financimit të terrorizmit

23. "http://www.bankofalbania.org/ëeb/Rregullore_Nr_44_Per_parandalimin_e pastrimitte parave dhe_financimi_1329_1.php

24. www.us.congres.com

25. www.ustreas.gov 